\title{
Zadovoljstvo klijenata pruženom uslugom ljekarnika u vrijeme epidemije bolesti COVID-19
}

1 Dora Rašan

1 Suzana Marković

1 Jelena Dorčić

2 Lovro Rašan

1 Fakultet za menadžment u turizmu i ugostiteljstvu, Sveučilište u Rijeci

2 Odjel za biotehnologiju, Sveučilište u Rijeci

\section{Sažetak}

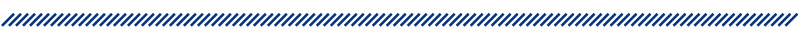

Uvod: Pojavom epidemije bolesti COVID-19 ljekarne su se susrele $s$ dosad nezabilježenom potražnjom za dezinficijensima, antisepticima te zaštitnim maskama. Ljudi su u većoj mjeri počeli odlaziti u ljekarne, koje su se morale od početka epidemije strogo pridržavati mjera sigurnosti. Uloga ljekarnika u navedenim okolnostima postala je još važnija.

Cilj i metode: Cilj ovog rada bio je istražiti i analizirati stavove klijenata ljekarni o kvaliteti usluge, analizirati njihovo sveukupno zadovoljstvo te ispitati razinu straha od bolesti COVID-19. U tu svrhu na temelju relevantne znanstvene literature kreiran je upitnik koji je distribuiran putem interneta. U mjerenju kvalitete usluge ljekarnika primijenjen je modificirani mjerni instrument SERVQUAL. Istraživanje je provedeno na uzorku od 203 klijenata ljekarni.

Rezultati: Rezultatima provedenoga empirijskog istraživanja utvrđeno je da ispitanici posjeduju visoka očekivanja o kvaliteti usluga ljekarnika $(3,93)$. Ukupna percepcija ispitanika pružene usluge ljekarnika iznosi 3,54, što ukazuje na činjenicu da je prisutan negativan SERVQUAL jaz između percepcije i očekivanja ispitanika $(-0,39)$. Negativan jaz bio je najveći pri ocjeni varijable „Ljekarnik bi me trebao uputiti što učiniti ako propustim dozu lijeka" $(-1,60)$, a najveći pozitivan jaz pri vrednovanju varijable "Ljekarnik je riješio sve zdravstvene probleme koje sam očekivao" $(+0,82)$. Ispitanici su bili zadovoljni ukupnom pruženom uslugom ljekarnika $(4,53)$ te su prilikom posjeta ljekarni osjećali srednju razinu straha od bolesti COVID-19 $(3,03)$.

Zaključak: Istraživanje zadovoljstva klijenata pruženom uslugom ljekarnika od krucijalnog je značaja za poboljšanja i unaprjeđenja postojeće kvalitete usluge ljekarnika. Istraživanje je pokazalo da je SERVQUAL prikladan mjerni instrument za mjerenje razlike u očekivanjima i percepciji klijenata o kvaliteti usluga ljekarnika.

Ključne riječi: kvaliteta ljekarničkih usluga, zadovoljstvo klijenata, SERVQUAL, statistička analiza, strah od bolesti COVID-19

Datum primitka: 01.09.2020.

Datum prihvaćanja: 15.09.2020.

https://doi.org/10.24141/1/6/2/4

Adresa za dopisivanje:

Suzana Marković

A: Sveučilište u Rijeci, Fakultet za menadžment u turizmu i ugostiteljstvu, Opatija, Hrvatska

E-pošta: suzanam@fthm.hr

T: +385992455901 


\section{Uvod}

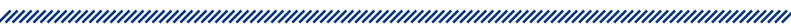

Zdravlje i očuvanje zdravlja važan je dio života svakog pojedinca. Kod sanacije i rješavanja većine zdravstvenih oboljenja primjenjuje se terapija u obliku lijeka koji mora odobriti ljekarnik te mora biti primijenjen u propisanim dozama. Ljekarnici se smatraju jednim od najdostupnijih zdravstvenih djelatnika. ${ }^{1}$ Shodno tome, u posljednjih nekoliko godina pridaje se sve veći značaj ljekarniku u liječenju ljudi.

Ljekarnici su zdravstveni stručnjaci odgovorni za distribucija lijekova klijentima i omogućuju sigurnu i učinkovitu uporabu lijekova. ${ }^{2}$ Uloga ljekarnika u Hrvatskoj u posljednjih se 40 godina promijenila, i to od osobe koja je miješala i izdavala lijekove u ulogu osobe koja upravlja terapijom lijekovima. ${ }^{3}$ Prema SZO-u, ${ }^{4}$ glavna je uloga ljekarnika tumačenje vrijednosti lijekova klijentima, kako bi klijenti posjedovali odgovarajuće znanje o tim lijekovima. Veliki broj autora ljekarničke usluge definira kao sve usluge koje su potrebne da se riješe bolesnikovi problemi s terapijom lijekovima. Raspon je tih usluga od davanja informacija o lijekovima preko davanja savjeta bolesnicima do distribucije lijekova. ${ }^{3}$

Od ljekarnika se očekuje pozitivna interakcija s klijentom i da se tijekom te interakcije klijentu objasni pravilna uporaba lijeka kako bi se izgradilo međusobno povjerenje. Isto se tako od ljekarnika očekuje da zaštiti privatnost klijenta, objasni klijentu moguće nuspojave lijeka, načine na koje se lijek mora skladištiti i da se interesira o drugim lijekovima koje klijent uzima. Stoga je od iznimne važnosti da ljekarnik ulaže svoju energiju u dobru komunikaciju i razumijevanje klijenta u cilju postizanja što bolje kvalitete usluge, što će u konačnici utjecati na cjelokupno zadovoljstvo klijenta.

Ljekarništvo je danas kompleksan skup tehničkih, međuljudskih i konceptualno integriranih procesa. ${ }^{5}$ lako posljednjih desetljeća raste svijest o važnosti pružanja kvalitetne ljekarničke usluge, u literaturi je moguće pronaći svega nekoliko empirijskih istraživanja koja su se bavila problematikom kvalitete usluga i zadovoljstva klijenata pruženom ljekarničkom uslugom. Polazeći od navedenog, cilj ovog empirijskog istraživanja bio je istražiti i analizirati stavove klijenata ljekarni o kvaliteti usluge, analizirati njihovo sveukupno zadovoljstvo te ispitati razinu straha od bolesti COVID-19.

\section{Teorijski okvir}

U teorijskom dijelu rada opisat će se koncept kvalitete usluga i zadovoljstva klijenta te će se ukratko objasniti modeli koji su primijenjeni $u$ istraživanjima zadovoljstva klijenata pruženim uslugama u ljekarni.

\section{Kvaliteta usluga i zadovoljstvo klijenata}

Koncept kvalitete usluga počinje plijeniti pažnju velikog broja autora 80 -ih godina 20. stoljeća. Do danas je navedeni koncept istraživan u mnogim područja i disciplinama unutar društvenih znanosti. Oliver ${ }^{6}$ definira kvalitetu usluge kao „razliku između stvarne performanse usluge i njihovih očekivanja", dok su Parasuraman i sur. ${ }^{7}$ kvalitetu usluge okarakterizirali kao „stupanj i smjer odstupanja između opažanja i očekivanja klijenata". Očekivanja klijenata u tom se kontekstu smatraju procjenom vrijednosti prije kupnje, dok se percepcijom klijenta smatra dobivena vrijednost kupnjom i pruženom uslugom.

Iznimno je važno istaknuti povezanost između pojmova kvaliteta usluga i zadovoljstvo. Postavlja se pitanje je li kvaliteta usluga temelj zadovoljstva ili je obratno. Većina znanstvenika ipak smatra da je kvaliteta usluga prethodnica zadovoljstva klijenta, dok manji broj znanstvenika smatra suprotno, odnosno da je zadovoljstvo temelj kvalitete usluga. Swan i Combs ${ }^{8}$ definiraju zadovoljstvo klijenta kao „ocjenu ili spoznaju konačnih korisnika o zadovoljavajućem ili nezadovoljavajućem proizvodu”, a Parasuraman, Zeithaml, i Berry ${ }^{9}$ kao „rezultat klijentove ocjene kvalitete usluge, kvalitete proizvoda i cijene".

S obzirom na činjenicu da se u ovom istraživanju naglasak stavlja na ljekarničke usluge, zadovoljstvo klijenata u tom se slučaju može definirati kao subjektivna ocjena temeljena na dosadašnjem iskustvu o svakom segmentu pružene usluge, od davanja informacija o lijekovima, preko uspostavljanja kvalitetne komunikacije između klijenta i ljekarnika, pa sve do prodaje lijekova.

\section{Mjerenje kvalitete usluga i zadovoljstva klijenata}

Najpoznatiji model za mjerenje kvalitete usluga i zadovoljstva klijenata jest SERVQUAL. ${ }^{10}$ Glavna je zadaća modela SERVQUAL pronalaženje jaza (engl. gap) između percepcije klijenata nakon što im je usluga pružena (engl. perceptions) i njihovih očekivanja (engl. expectations) prije pružanja usluge. Determiniranje jazova pružateljima usluge omogućuje unaprjeđenje i poboljšanje cjelokupnog procesa. 
U slučaju da je percepcija klijenta vrednovana višom ocjenom od njihovih očekivanja, tada su klijentova očekivanja nadmašena, točnije, može se reći da su klijenti oduševljeni kvalitetom pružene usluge. Ako su klijentova očekivanja ispunjena, kvaliteta usluge poima se kao zadovoljavajuća, dok nezadovoljenje očekivanja klijentu pobuđuje nezadovoljstvo. Mjerenje kvalitete usluga veoma je kompleksno jer su usluge nematerijalne, neopipljive, kratkotrajne i zahtijevaju simultanu proizvodnju i potrošnju. Rezultati prethodnih istraživanja provedenih u različitim uslužnim djelatnostima i u različitim kulturnim i geografskim područjima ukazuju da je model SERVQUAL koristan i pouzdan instrument za vrednovanje pružene kvalitete usluga sa stajališta klijenta. Međutim, u literaturi je moguće naći i brojne kritike koje se uglavnom odnose na univerzalnost mjernog instrumenta te nestabilnost odnosa varijabli i faktora, kao i problem mjerenja očekivanja. ${ }^{11,12}$ Stoga, većina istraživača savjetuje da se sam instrument prilagodi uslužnoj djelatnosti u kojoj se namjerava provesti istraživanje te da se u obzir uzmu kulturne i sociodemografske karakteristike klijenata.

Istraživanja kvalitete usluga i zadovoljstva klijenata pruženom uslugom ljekarnika počela su se provoditi krajem 90-ih godina 20. stoljeća. Jedno od prvih istraživanja u ovom području proveli su Douglas i sur., ${ }^{13} \mathrm{koji}$ su primijenili model SERVQUAL u svojem istraživanju za mjerenje razine zadovoljstva pacijenata pruženom uslugom ljekarnika. U svojem istraživanju fokusirali su se na pacijente koji boluju od astme te su na temelju rezultata istraživanja došli do zaključka da je zadovoljstvo pacijenata povezano s razinom brige ljekarnike i njihove percepcije o sposobnosti ljekarnika da im pomogne u prevenciji i rješavanju problema astme.

Sriwong ${ }^{14}$ je modificirao i prilagodio model SERVQUAL za mjerenje kvalitete ljekarničkih usluga te je svoj mjerni instrument nazvao PHARM-SERVQUAL. Mjerni instrument sadrži 30 čestica koje su grupirane u četiri dimenzije, a to su: 1 ) savjetovanje klijenta o lijekovima bez recepta, 2) savjetovanje klijenata o lijekovima na recept, 3) propisivanje lijekova bez recepta i 4) aktivnosti povezane s informiranjem klijenata o lijekovima.

Cortoševa \& Gavranska-Nečev ${ }^{15}$ također su u svojem istraživanju primijenile modificirani model SERVQUAL kako bi odredile kvalitetu usluga u farmaceutskoj maloprodaji u šest ljekarni u Skopju u Makedoniji. Njihovo istraživanje također je potvrdilo da je model SERVQUAL koristan instrument za mjerenje percepcije i očekivanja klijenata ljekarni te pruža mogućnost brzog uvida u prednosti i nedostatke usluga.
Neka istraživanja pokušala su kreirati nove instrumente za mjerenje kvalitete usluga i zadovoljstva klijenata pruženom uslugom ljekarnika. Primjerice, Hasan i sur. ${ }^{16}$ kreirali su koristan instrument za mjerenje zadovoljstva pacijenata tradicionalnim ljekarničkim uslugama (tj. usluge usmjerene na proizvode uz pružanje minimalne ili zanemarive farmaceutske njege), dok su Hernández i sur. ${ }^{17}$ u svojem istraživanju kreirali pouzdanu i valjanu ljestvicu za mjerenje zadovoljstva pacijenata pruženom uslugom ljekarnika.

Provedeno empirijsko istraživanje zasniva se prvenstveno na stranoj literaturi sobzirom na to da u domaćoj literaturi nisu pronađeni znanstveni i stručni članci koji odgovaraju temi istraživanja. Shodno tome, ovo istraživanje ima osobitu i veliku važnost jer da istovjetna istraživanja u Hrvatskoj još nisu bila provedena i može poslužiti za unaprjeđenje kvalitete usluga koje pružaju ljekarnici.

\section{Rezultati empirijskog istraživanja}

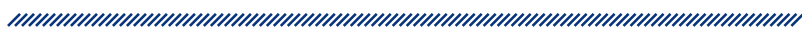

\section{Cilj istraživanja}

Ciljevi empirijskog istraživanja bili su: a) utvrditi očekivanu i percipiranu kvalitetu ljekarničkih usluga, b) izračunati jaz između percepcije i očekivanja klijenata o kvaliteti ljekarničke usluge, c) ocijeniti stupanj zadovoljstva klijenata pruženom uslugom ljekarnika, d) ispitati razinu straha klijenata od bolesti COVID-19.

\section{Metodologija istraživanja}

Za potrebe ovog empirijskog istraživanja upotrijebljeni su primarni podaci dobiveni metodom anketiranja klijenata ljekarni. S obzirom na situaciju izazvanu bolešću COVID-19, nije bilo moguće fizički distribuirati upitnike u ljekarnama te se kao opcija nametnula provedba istraživanja putem interneta. Anketni upitnik distribuiran je putem društvenih mreža i vlastitih kontakata istraživača te je ispitivanje provedeno u periodu od travnja do svibnja 2020.

Anketni upitnik sastojao se od pet cjelina te je sadržavao ukupno 65 čestica. Struktura anketnoga upitnika prikazana je u tablici 1. 


\begin{tabular}{|c|c|c|}
\hline \multicolumn{2}{|c|}{ Tablica 1. Struktura mjernog instrumenta } \\
(upitnik)
\end{tabular}

U prvom su dijelu anketnog upitnika s pomoću 23 tvrdnje ocijenjena očekivanja klijenata povezana s kvalitetom usluga ljekarnika. Drugi dio upitnika sastojao se od 23 sukladne tvrdnje kojima je ocijenjena percepcija kvalitete pruženih ljekarničkih usluga. Osnova za kreiranje ovog dijela anketnog upitnika bilo je istraživanje koje su proveli Tinelli i sur. ${ }^{18}$ Treći dio anketnog upitnika ispitivao je sveukupno zadovoljstvo klijenata pruženom uslugom ljekarnika uz pomoć sljedeće tvrdnje: „Kako ocjenjujete pruženu uslugu ljekarnika?" Četvrti dio anketnog upitnika sastojao se od devet tvrdnji kojima se mjerila razina straha klijenata od bolesti COVID-19, a tvrdnje su preuzete iz istraživanja koje su proveli Mertens i sur. ${ }^{19}$ Ispitanici uključeni $u$ istraživanje tvrdnje sadržane u prve četiri cjeline mjernoga instrumenta ocjenjivali su na Likertovoj ljestvici od pet stupnjeva, s krajnjim mjerama „potpuno se ne slažem” (1) i „potpuno se slažem" (5).

U posljednjem dijelu anketnog upitnika nalaze se tvrdnje uz pomoć kojih je analiziran sociodemografski profil ispitanika: dob, spol, bračni status, stupanj obrazovanja, mjesečna primanja, učestalost posjeta ljekarni, iznos financijskih sredstava na godišnjoj razini izdvojenih za lijekove i načini izdavanja lijekova (na recept ili bez recepta).

\section{Rezultati statističke analize}

$\mathrm{Na}$ temelju istraživanja zadovoljstva pruženom uslugom ljekarnika dolazi se do rezultata statističke analize podataka koji su prikazani u tablicama u nastavku. Prvo je opisan sociodemografski profil ispitanika, a nakon toga slijedi prikaz rezultata deskriptivne statističke analize.

\begin{tabular}{|c|c|c|}
\hline \multirow{3}{*}{$\begin{array}{l}\text { Karakteristike } \\
\text { ispitanika }\end{array}$} & \multirow{2}{*}{\multicolumn{2}{|c|}{ FREKVENCIJE }} \\
\hline & & \\
\hline & APSOLUTNE & $\begin{array}{c}\text { RELATIVNE } \\
(\%)\end{array}$ \\
\hline \multicolumn{3}{|c|}{ Spol } \\
\hline Muški & 61 & 29,7 \\
\hline Ženski & 142 & 70,3 \\
\hline \multicolumn{3}{|c|}{ Dob } \\
\hline $16-25$ & 86 & 42,4 \\
\hline $26-35$ & 23 & 11,3 \\
\hline $36-45$ & 40 & 19,7 \\
\hline $46-55$ & 37 & 18,2 \\
\hline $56-65$ & 15 & 7,4 \\
\hline više od 66 & 2 & 1 \\
\hline \multicolumn{3}{|c|}{ Bračni status } \\
\hline u braku & 82 & 40,4 \\
\hline u vezi / zaručen & 50 & 24,6 \\
\hline neoženjen/neudana & 71 & 35 \\
\hline \multicolumn{3}{|l|}{$\begin{array}{c}\text { najviši stupanj } \\
\text { obrazovanja }\end{array}$} \\
\hline osnovna škola ili niže & 2 & 1 \\
\hline srednja škola & 104 & 51,2 \\
\hline viša škola ili fakultet & 91 & 44,8 \\
\hline poslijediplomski studij & 6 & 3 \\
\hline
\end{tabular}

\begin{tabular}{|c|c|c|}
\hline \multicolumn{3}{|c|}{ Radni status } \\
\hline $\begin{array}{c}\text { zaposlen s nepunim } \\
\text { radnim vremenom }\end{array}$ & 3 & 1,5 \\
\hline $\begin{array}{c}\text { zaposlen s punim } \\
\text { radnim vremenom }\end{array}$ & 111 & 54,7 \\
\hline samozaposlen & 6 & 3 \\
\hline nezaposlen & 5 & 2,5 \\
\hline umirovljenik & 6 & 3 \\
\hline učenik/student & 72 & 35,5 \\
\hline Mjesečna primanja / kn & \\
\hline do 3.500,00 & 26 & 12,8 \\
\hline $3.501,00-5.000,00$ & 23 & 11,3 \\
\hline $5.001,00-1.0000,00$ & 86 & 42,4 \\
\hline $10.001,00-15.000,00$ & 15 & 7,4 \\
\hline više od 15.000,00 & 4 & 2 \\
\hline nemam primanja & 49 & 24,1 \\
\hline
\end{tabular}




\begin{tabular}{|c|c|c|}
\hline \multirow{2}{*}{$\begin{array}{l}\text { Karakteristike } \\
\text { ispitanika }\end{array}$} & \multicolumn{2}{|c|}{ FREKVENCIJE } \\
\hline & APSOLUTNE & $\begin{array}{l}\text { RELATIVNE } \\
(\%)\end{array}$ \\
\hline \multicolumn{3}{|c|}{$\begin{array}{l}\text { Izdvajanje financijskih sredstava godišnje na lijekove } \\
\qquad \text { (iznos u kunama) }\end{array}$} \\
\hline do 200,00 & 73 & 36 \\
\hline $201,00-600,00$ & 87 & 42,9 \\
\hline $601,00-1.000,00$ & 21 & 10,3 \\
\hline više od $1.000,00$ & 22 & 10,8 \\
\hline \multicolumn{3}{|c|}{ Učestalost posjeta ljekarni } \\
\hline više puta mjesečno & 29 & 14,3 \\
\hline jednom mjesečno & 66 & 32,5 \\
\hline jednom u tri mjeseca & 62 & 30,5 \\
\hline jednom u šest mjeseci & 37 & 18,2 \\
\hline jednom godišnje & 9 & 4,4 \\
\hline \multicolumn{3}{|c|}{ Način izdavanja lijeka } \\
\hline na recept & 101 & 49,7 \\
\hline bez recepta & 102 & 50,3 \\
\hline
\end{tabular}

Iz tablice 2 vidljivo je da je od 203 ispitanika obuhvaćenih istraživanjem bila veća zastupljenost žena (70,3\%) u odnosu na muškarce (29,7 \%).

Dobna struktura ispitanih korisnika podijeljena je u šest skupina. Najveći je broj ispitanika u dobi između 16 i 25 godina (42,4\%). Nakon toga slijede klijenti u dobi od 36 do 45 godina koji čine 19,7 \% uzorka i klijenti u dobi od 46 do 55 godina koji čine 18,2 \% uzorka. Najmanji broj ispitanika bio je u dobnoj skupini više od 66 godina $(1 \%)$.

S obzirom na bračni status, u braku je $40,4 \%$ ispitanika, neoženjenih/neudanih je $35 \%$ ispitanika, a u vezi odnosno zaručenih $24,6 \%$ ispitanika. Prema stupnju obrazovanja, najveći broj ispitanika ima završenu srednju školu (51,2 \%) i visoku školu ili fakultet (44,8 \%), a najmanji broj ispitanika ima završenu osnovnu školu ili niže (1\%). Od ukupnog broja ispitanika najveći je broj zaposlenih s punim radnim vremenom (54,7\%) te gotovo polovica ispitanika $(42,4 \%)$ ima mjesečna primanja od 5.001,00 do 10.000,00 kuna.

Prema učestalosti posjeta ljekarni najveći se broj ispitanika koristi uslugama ljekarne jednom mjesečno (32,5\%), a samo se $4,4 \%$ ispitanika koristi uslugama ljekarne jednom godišnje. Prema izdvajanju financijskih sredstava na lijekove, najveći broj ispitanika troši od 201,00 do 600,00 kuna godišnje (42,9\%), dok najmanji broj ispitanika izdvaja od 601,00 do $1.000,00$ kuna godišnje (10,3\%). S obzirom na način izdavanja lijekova postoji minorna razlika, odnosno veći broj ispitanika (50,3\%) kupuje lijekove bez recepta, a 49,7 \% ispitanika kupuje lijekove na recept.

Analizom uzorka definirane su temeljne sociodemografske karakteristike klijenata ljekarne koji su pristali sudjelovati u ovom empirijskom istraživanju. Utvrđeno je da je u uzorku zastupljen veći broj žena u odnosu na muškarce. Većina je ispitanika mlađe životne dobi i imaju srednje ili više i visoko obrazovanje.

Prema dobivenim rezultatima iz tablice 3 , vidljivo je da su ispitani klijenti imali visoka očekivanja povezana s kvalitetom usluge ljekarnika s ukupnom prosječnom ocjenom od 3,93. Osim visoke ukupne prosječne ocjene očekivanja klijenata, također je prisutna visoka prosječna ocjena isporučene kvalitete usluga ljekarnika u iznosu od 3,54. Oduzimanjem ukupnih prosječnih ocjena percepcije i očekivanja utvrđen je SERVQUAL jaz koji iznosi -0,39.

Najviše ocijenjena tvrdnja kod očekivanja $(4,95)$ i kod percepcije klijenata $(4,92)$ odnosi se na čistoću i urednost ljekarnika. S druge strane, ispitanici najmanje očekuju da ljekarnik riješi sve njihove zdravstvene tegobe $(1,99)$. Na ljestvici percepcije najnižom prosječnom ocjenom ocijenjena je tvrdnja „Ljekarnik je razgovarao privatno sa mnom" $(2,07)$.

Moguće je ustanoviti da je od ukupno 23 tvrdnje samo kod šest tvrdnji prisutan pozitivan SERVQUAL jaz, što znači da su u cjelini očekivanja veća od percepcije klijenata te da su premašena očekivanja. Najveći negativni SERVQUAL jaz prisutan je za tvrdnju „Ljekarnik bi me trebao uputiti što učiniti ako propustim dozu lijeka" $(-1,60)$, a najveći pozitivan SERVQUAL jaz odnosi se na česticu „Ljekarnik bi trebao riješiti sve zdravstvene probleme koje očekujem" $(+0,89)$.

S obzirom na kontekst istraživanja, važno je naglasiti da u je tri tvrdnje koje su odnosile na poduzimanje mjera ljekarnika zbog pojave bolesti COVID-19 kod dvije tvrdnje prisutan pozitivan SERVQUAL jaz: nošenje propisane opreme ljekarnika $(+0,05)$ i vođenje evidencije o razmaku između klijenata $(+0,11)$.

Osim navedenih tvrdnji, pozitivan SERVQUAL jaz utvrđen je kod čestica: „Ljekarnik bi trebao osigurati da ne čekam dugo na svoj lijek” (+0,32), „Ljekarnik bi se trebao istinski zanimati za moje zdravstvene tegobe" $(+0,06)$ i '"Ljekarnik bi trebao zadovoljavajuće odgovoriti na moja pitanja" $(+0,06)$. 


\section{Tablica 3. Rezultati deskriptivne statističke analize $(\mathbf{N}=\mathbf{2 0 3})$}

\begin{tabular}{|c|c|c|c|c|c|}
\hline \multirow[b]{2}{*}{ Čestica } & \multicolumn{2}{|c|}{ OČEKIVANJA } & \multicolumn{2}{|c|}{ PERCEPCIJA } & \multirow{2}{*}{$\begin{array}{l}\text { SERVQUAL } \\
\quad \text { jaz }\end{array}$} \\
\hline & $\begin{array}{c}\text { prosječna } \\
\text { ocjena }\end{array}$ & $\begin{array}{l}\text { standardna } \\
\text { devijacija }\end{array}$ & $\begin{array}{l}\text { prosječna } \\
\text { ocjena }\end{array}$ & $\begin{array}{l}\text { standardna } \\
\text { devijacija }\end{array}$ & \\
\hline Ljekarnik bi trebao biti uredan i čist. & 4,95 & 0,217 & 4,92 & 0,320 & $-0,03$ \\
\hline $\begin{array}{l}\text { Ljekarnik bi se prema meni trebao odnositi s } \\
\text { poštovanjem. }\end{array}$ & 4,85 & 0,424 & 4,81 & 0,534 & $-0,04$ \\
\hline Ljekarnik bi trebao čuvati moju privatnost. & 4,89 & 0,413 & 4,51 & 0,881 & $-0,38$ \\
\hline $\begin{array}{c}\text { Ljekarnik bi trebao razgovarati s mojim liječnikom } \\
\text { o propisanom lijeku. }\end{array}$ & 3,41 & 1,176 & 2,30 & 1,507 & $-1,11$ \\
\hline $\begin{array}{l}\text { Ljekarnik bi mi trebao pomoći u donošenju odluke } \\
\text { je li propisani lijek odgovarajući za mene. }\end{array}$ & 3,78 & 1,256 & 2,44 & 1,476 & $-1,34$ \\
\hline $\begin{array}{l}\text { Ljekarnik bi mi trebao objasniti kako uzimati } \\
\text { odgovarajući lijek. }\end{array}$ & 4,87 & 0,394 & 4,56 & 0,862 & $-0,31$ \\
\hline $\begin{array}{l}\text { Ljekarnik bi me trebao uputiti što učiniti ako } \\
\text { propustim dozu lijeka. }\end{array}$ & 4,51 & 0,951 & 2,91 & 1,707 & $-1,60$ \\
\hline $\begin{array}{l}\text { Ljekarnik bi me trebao obavijestiti o mogućim } \\
\text { nuspojavama. }\end{array}$ & 4,36 & 1,045 & 2,79 & 1,703 & $-1,57$ \\
\hline $\begin{array}{l}\text { Ljekarnik bi mi trebao pružiti informacije o } \\
\text { pravilnom skladištenju lijeka. }\end{array}$ & 4,14 & 1,161 & 2,71 & 1,685 & $-1,43$ \\
\hline $\begin{array}{l}\text { Ljekarnik bi se trebao uvjeriti da razumijem kako } \\
\text { treba uzimati odgovarajući lijek. }\end{array}$ & 4,30 & 0,966 & 3,74 & 1,468 & $-0,56$ \\
\hline Ljekarnik bi trebao razgovarati privatno sa mnom. & 2,50 & 1,394 & 2,07 & 1,418 & $-0,43$ \\
\hline $\begin{array}{l}\text { Ljekarnik bi trebao osigurati da ne čekam dugo na } \\
\text { svoj lijek. }\end{array}$ & 3,65 & 1,240 & 3,97 & 1,244 & 0,32 \\
\hline $\begin{array}{l}\text { Ljekarnik bi se trebao istinski zanimati za moje } \\
\text { zdravstvene tegobe. }\end{array}$ & 2,82 & 1,246 & 2,88 & 1,449 & 0,06 \\
\hline Ljekarnik bi moje brige trebao shvatiti ozbiljno. & 3,59 & 1,288 & 3,26 & 1,413 & $-0,33$ \\
\hline $\begin{array}{l}\text { Ljekarnik bi mi trebao dati priliku da postavljam } \\
\text { pitanja o odgovarajućem lijeku. }\end{array}$ & 4,53 & 0,706 & 4,10 & 1,198 & $-0,43$ \\
\hline $\begin{array}{l}\text { Ljekarnik bi trebao zadovoljavajuće odgovoriti na } \\
\text { moja pitanja. }\end{array}$ & 4,30 & 0,960 & 4,36 & 0,903 & 0,06 \\
\hline $\begin{array}{l}\text { Ljekarnik bi mi trebao objasniti moje zdravstveno } \\
\text { stanje na način koji ja razumijem. }\end{array}$ & 3,69 & 1,371 & 3,68 & 1,405 & $-0,01$ \\
\hline $\begin{array}{l}\text { Ljekarnik bi mi trebao dati informacije o mojem } \\
\text { zdravstvenom stanju, kao i o lijekovima koje uzimam. }\end{array}$ & 3,24 & 1,384 & 2,97 & 1,514 & $-0,27$ \\
\hline $\begin{array}{l}\text { Ljekarnik bi trebao riješiti sve zdravstvene } \\
\text { probleme koje očekujem. }\end{array}$ & 1,99 & 1,229 & 2,81 & 1,491 & 0,82 \\
\hline $\begin{array}{l}\text { Ljekarnik bi se trebao interesirati o drugim } \\
\text { lijekovima koje uzimam. }\end{array}$ & 3,27 & 1,404 & 2,72 & 1,584 & $-0,55$ \\
\hline $\begin{array}{l}\text { Ljekarnik bi trebao nositi propisanu opremu } \\
\text { (rukavice i masku) zbog bolesti COVID-19 prilikom } \\
\text { pružanja usluge. }\end{array}$ & 4,51 & 1,028 & 4,56 & 1,063 & 0,05 \\
\hline $\begin{array}{l}\text { Osoblje u ljekarni trebalo bi voditi evidenciju o } \\
\text { razmaku između klijenata zbog bolesti COVID-19. }\end{array}$ & 4,29 & 1,134 & 4,40 & 1,153 & 0,11 \\
\hline $\begin{array}{l}\text { Ljekarnik bi svakom klijentu trebao obaviti } \\
\text { provjeru statusa samoizolacije. }\end{array}$ & 3,95 & 1,412 & 3,89 & 1,573 & $-0,06$ \\
\hline UKUPNO & 3,93 & - & 3,54 & - & $-0,39$ \\
\hline
\end{tabular}


Na temelju prikazanog rezultata u tablici 4 moguće je zaključiti da su klijenti zadovoljni pruženom uslugom ljekarnika, što je moguće potkrijepiti visokom prosječnom ocjenom u iznosu od 4,53. Najniža je dobivena ocjena 2, a najveća 5.

Tablica 5 prikazuje dobivene rezultate za konstrukt strah od bolesti COVID-19. Prosječne ocjene ispitanika za navedeni konstrukt kreću se u rasponu od 2,12 do 4,28. Prosječna ocjena za tvrdnju „Jako sam zabrinut zbog izbijanja bolesti COVID-19" iznosi 3,01, iz čega je moguće zaključiti da klijenti nisu previše zabrinuti oko izbijanja virusa, ali većina klijenata poduzima sve mjere opreza kako bi spriječili infekciju $(4,28)$.

Gotovo polovica ispitanika opskrbila se zalihama kako bi se pripremila za probleme povezane s epidemijom bolesti COVID-19 $(2,43)$. Najniže je ocijenjena tvrdnja „Osjećam da zdravstvene vlasti ne čine dovoljno kako bismo se mogli nositi s virusom" $(2,12)$, što znači da se većina klijenata ne slaže $s$ navedenom tvrdnjom, točnije, da je većina klijenata zadovoljna s ukupnim angažmanom zdravstvenih vlasti.

Ukupna prosječna ocjena za konstrukt strah od bolesti COVID-19 iznosi 3,03 te s obzirom na to da su ocjene u anketnom upitniku bile formirane od 1 do 5 , može se reći da ispitanici osjećaju srednju razinu straha.

\section{Zaključak}

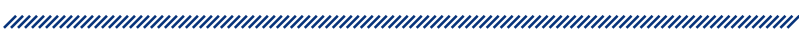

Za liječenje bilo koje vrste oboljenja primjenjuje se terapija lijekovima, a lijek mora odobriti ljekarnik. Iz tog je razloga uloga ljekarnika od iznimne važnosti, točnije, ljekarnici su zaduženi za davanja informacija o lijekovima, uspostavljanje kvalitetne komunikacije s klijentima i za prodaju lijekova. lako se koncept kvalitete usluga i zadovoljstva klijenata istražuje već više od tri desetljeća, u znanstvenoj i stručnoj literaturi postoji mali broj radova u kojima se istražuje i mjeri razina zadovoljstva klijenata pruženom uslugom ljekarnika. Postoji potreba da se saznaju očekivanja klijenata, sagleda percepcija pružene usluge, kao i razina sveukupnog zadovoljstva, da bi se poboljšala razina pružene ljekarničke usluge.

Rezultati statističke analize istraživanja zadovoljstva klijenata ljekarni u Hrvatskoj pokazali su da je negativan jaz prisutan kod 17 od ukupno 23 tvrdnje o kvaliteti usluga. Prosječna je ocjena očekivanja na ljestvici od pet stupnjeva 3,93, dok je prosječna ocjena na ljestvici percepcije 3,54 uz negativan SERVQUAL jaz od -0,39 između ocjene percepcije i očekivanja. Navedeno upućuje na to da ljekarnici nisu u potpunosti ispunili očekivanja svojih klijenata. Stoga je potrebno unaprjeđenje pojedinih stavki tijekom pružanja usluge koje će u konačnici utjecati i na podizanje kvalitete usluga.

\begin{tabular}{|c|c|c|c|c|}
\hline \multicolumn{5}{|c|}{ Tablica 4. Rezultati deskriptivne statističke analize zadovoljstva ispitanika (N = 203) } \\
\hline Čestica & Minimum & Maksimum & prosječna ocjena & standardna devijacija \\
\hline $\begin{array}{c}\text { Kako ocjenjujete pruženu uslugu } \\
\text { ljekarnika? }\end{array}$ & 2 & 5 & 4,53 & 0,655 \\
\hline
\end{tabular}

\begin{tabular}{|c|c|c|}
\hline \multicolumn{2}{|c|}{ Tablica 5. Strah od bolesti COVID-19 } \\
\hline Čestice & $\begin{array}{c}\text { prosječna } \\
\text { ocjena }\end{array}$ & $\begin{array}{c}\text { standardna } \\
\text { devijacija }\end{array}$ \\
\hline Jako sam zabrinut zbog izbijanja bolesti COVID-19. & 3,01 & 1,247 \\
\hline Poduzimam mjere opreza da spriječim infekciju. & 4,28 & 0,913 \\
\hline Neprestano pratim sve novosti o bolesti CovID-19. & 3,12 & 1,305 \\
\hline Opskrbio sam se zalihama kako bih se pripremio za probleme povezane sepidemijom koronavirusa. & 2,43 & 1,274 \\
\hline Za svoje osobno zdravlje, smatram da je bolest CovID-19 mnogo opasniji od sezonske gripe. & 3,19 \\
\hline Osjećam da zdravstvene vlasti ne čine dovoljno kako bismo se mogli nositi s virusom. & 2,12 \\
\hline Zabrinut sam da će moji prijatelji i obitelj biti zaraženi. & 1,412 \\
\hline Poduzimam više mjera opreza u odnosu na većinu ljudi da se ne zarazim. & 3,09 \\
\hline UKUPNo & 2,99 \\
\hline
\end{tabular}


Najvišim prosječnim ocjenama vrednovana je čestica kod očekivanja i percepcije klijenata koja se odnosi na čistoću i urednost ljekarnika. Naime, klijenti ljekarne najčešće su imunosuprimirane osobe te izlaganje uvjetima niske higijenske razine šteti organizmu. Ispitanici ne očekuju da ljekarnik rješava njihove zdravstvene tegobe $i$ to je ujedno varijabla koja je ocijenjena najniže. U prilog tome ide činjenica kako pola ispitanika u ljekarni uzima lijekove na recept, to jest lijek koji je propisao liječnik. Također se može zaključiti da klijenti osjećaju visok stupanj zadovoljstva pruženom uslugom ljekarnika, što je moguće potkrijepiti visokom prosječnom ocjenom u iznosu od 4,53.

Prema ovom istraživanju, ispitanici nisu previše zabrinuti izbijanjem bolesti COVID-19. Prema dobivenim rezultatima, ljekarnici generalno pružaju visoku kvalitetu usluge te na pravilan način tretiraju klijente pri pojavnosti bolesti COVID-19.

Ograničenje provedenog empirijskog istraživanja odnosi se prije svega na metodu prikupljanja podataka i uzorak. Iz opravdanih razloga (epidemija bolesti COVID-19) istraživanje je provedeno putem interneta, čime je ujedno smanjena reprezentativnost samog uzorka. Potrebno je u budućim istraživanjima uključiti ljekarne koje će pomoći u direktnoj distribuciji upitnika te time omogućiti da uzorak bude reprezentativniji. Osim navedenog, buduća istraživana trebala bi sagledati kvalitetu ljekarničkih usluga i iz drugih aspekata osim iz perspektive klijenata te ispitivanjem obuhvatiti i stručnjake i djelatnike koji će kvalitetu usluga ocijeniti s profesionalnog gledišta. Budući da je u znanstvenoj i stručnoj literaturi zastupljen mali broj istraživanja koja se bave istraživanjem zadovoljstva pruženom uslugom ljekarnika, ovo istraživanje može poslužiti kao podloga za buduća istraživanja. U nedavno objavljenom istraživanju Dukić i Medarićs analizirajući stavove zaposlenika ljekarni došli su do zaključka da, iako je većina ljekarni u Hrvatskoj usmjerena na klijente, u nedovoljnoj se mjeri primjenjuju odgovarajuće tehnike i metode kojima bi se kontinuirano pratilo zadovoljstvo klijenata. Upravo instrument primijenjen u ovom istraživanju može poslužiti menadžmentu ljekarni da dođu do informacija o očekivanjima i potrebama svojih klijenata, kao i o njihovoj percepciji pružene usluge i sveukupnom zadovoljstvu. Na temelju takvih istraživanja menadžment ljekarni moći će lakše determinirati svoje snage i slabosti u poslovanju i u konačnici unaprijediti kvalitetu svojih usluga.

\section{Referencije}

1. National Center for Chronic Disease Prevention and Health Promotion. A program guide for public health: Partnering with the pharmacist in the prevention and control of chronic diseases, 2012, Atlanta: Centers for Disease Control and Prevention. Dostupno na: https:// www.cdc.gov/dhdsp/programs/spha/docs/Pharmacist Guide.pdf (pristupljeno 2.9.2020.).

2. Dagsi M, Fontanilla RM, Galigaro CV, Guerrero J, Lai S, Orpilla $\mathrm{Cl}$, Querubin KMT. Service quality of pharmacies in Candon city. Department of education, 2017, 1-48. Dostupno na: doi: https://doi.org/10.13140/RG.2.2.17242.85449

3. Portolan M, Jonjić D, Grundler A. Hrvatska ljekarnička komora: ljekarnici u skrbi za bolesnika, 2011, Zagreb: Hrvatska ljekarnička komora.

4. World Health Organization. [Internet]; 2015. Dostupno na: www.empr.com/news/world-health-organization-antibioticscommon-infection-essentials-meds/article/667977 (pristupljeno 5.5.2020.).

5. Dukić G, Medarić D. Ljekarnički menadžment u Hrvatskoj. Ekonomska misao i praksa [Internet]. 2019, (1): 23-51. Dostupno na: https://hrcak.srce.hr/221024

6. Oliver R. A cognitive model of the antecedents and consequences of satisfaction decisions. Journal Marketing Research, 1980, 17: 460-469. Dostupno na: https://doi. org/10.2307/3150499

7. Parasuraman A, ZeithamI VA, Berry LL. A multi-item scale for measuring consumer perceptions of service quality. Journal of Marketing, 1988, 64(1): 12-40.

8. Swan JE, Combs LJ. Product performance and consumer satisfaction: A new concept. Journal of Marketing, 1976, 40(2): 25-33.

9. Parasuraman A, Zeithaml VA, Berry LL. Research note: More on improving service quality measurement. Journal of Retailing, 1993, 69(1): 140-147. Dostupno na: doi: 10.1016/S0022-4359(05)80007-7

10. Parasuraman A, Zeithaml VA, Berry LL. A Conceptual Model of Service Quality and Its Implications for Future Research. Journal of Marketing, 1985, 49(4): 41-50. Dostupno na: https://doi.org/10.1177/002224298504900403

11. Buttle F. SERVQUAL: review, critique, research agenda, European Journal of Marketing, 1996, 30(1): 8-32. Dostupno na: https://doi.org/10.1108/03090569610105762

12. Asubonteng P, McCleary KJ, Swan JE. SERVQUAL revisited: a critical review of service quality. Journal of Services marketing, 1996, 10(6): 62-81. Dostupno na: https:// doi.org/10.1108/08876049610148602

13. Douglas Ried L, Wang F, Young H, Avviphan R. Patients' Satisfaction and Their Perception of the Pharmacist. Journal of the American Pharmaceutical Association (1996), 1999, 39(6): 835-842. Dostupno na: https://doi. org/10.1016/s1086-5802(15)30375-2 
14. Sriwong, Burin T. Application of Quality Gap Model to Measure the Quality of Pharmacist Service in Retail Pharmacy Settings: An Examination of Expectation and Perception. Thai Bulletin of Pharmaceutical Sciences, 2004, 1(1): 89-100. Dostupno na: https://doi.org/10.14456/ tbps. 2004.9

15. Ćortoševa S, Gavranska-Nečev E. Research of costumer service satisfaction in pharmaceutical retail by SERVQUAL model. Journal of engineering \& processing management, 2016, [s. l.]: 33-44. Dostupno na: https://jepm.tfzv. ues.rs.ba/index.php/Journal/article/view/30

16. Hasan S, Sulieman H, Stewart K, Chapman CB, Hasan MY, Kong DCM. Assessing patient satisfaction with community pharmacy in the UAE using a newly-validated tool. Research in Social and Administrative Pharmacy, 2013, 9(6): 841-850. Dostupno: https://doi.org.10.1016/j.sapharm.2012.10.002
17. Hernández L, Chang CH, Cella D, Corona M, Shiomoto G, McGuire DB. Development and Validation of the Satisfaction with Pharmacist Scale. Pharmacotherapy, 2000, 20(7): 837-843. Dostupno na: https://doi.org.10.1592/ phco.20.9.837.35188

18. Tinelli M, Bond C, Blenkinsopp A, Jaffray M, Watson M, Hannaford P. Patient evaluation of a community pharmacy medications management service. Annals of Pharmacotherapy, 2007, 41(12): 1962-1970. Dostupno na: https://doi.org/10.1345/aph.1K242

19. Mertens G, Gerritsen L, Salemink E, Engelhard IM. Fear of the coronavirus (COVID-19): Predictors in an online study conducted in March 2020, Journal of Anxiety Disorders, 2020, (74): 102258. Dostupno na: https://doi. org/10.1016/j.janxdis.2020.102258 


\section{CUSTOMER SATISFACTION WITH THE PROVISION OF PHARMACY SERVICES DURING THE COVID-19 EPIDEMIC}

1 Dora Rašan

1 Suzana Marković

1 Jelena Dorčić

2 Lovro Rašan

1 Faculty of Tourism and Hospitality Management, University of Rijeka

2 Department of Biotechnology, University of Rijeka

\section{Abstract}

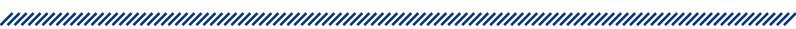

Introduction: With the outbreak of the epidemic COVID-19, pharmacies encountered unprecedented demand for disinfectants, antiseptics and protective masks. More and more people went to pharmacies, which had to strictly adhere to safety measures since the beginning of the epidemic. The role of the pharmacist became even more important under the circumstances mentioned above.

Objectives and methods: The aim of this study was to investigate and analyze the attitudes of pharmacy customers towards service quality, to analyze their overall satisfaction and to investigate the level of fear of the COVID-19 virus. For this purpose, a questionnaire was prepared on the basis of the relevant scientific literature and distributed online. A modified SERVQUAL model was used to measure the quality of the pharmacist's service. The survey was conducted on a sample of 203 pharmacy customers.
Results: The results of the empirical research indicates that the respondents have high expectations of the service quality provided by pharmacists (3.93). The respondents' overall perception of the service provided by the pharmacist is 3.54 , which indicates that there is a negative SERVQUAL gap between the perception and the expectation of the respondents (-0.39). The negative gap was largest in the evaluation of the variable "Pharmacist should tell me what to do if I miss a dose of the drug" (-1.60), and the largest positive gap in the evaluation of the variable "Pharmacist has solved all the health problems I expected" (+0.82). Respondents were satisfied with the overall service provided by the pharmacist (4.53) and felt a medium level of anxiety about the COVID-19 virus when visiting the pharmacy (3.03).

Conclusion: The investigation of customer satisfaction with the pharmacy service is decisive for improving and increasing the existing quality of the pharmacy service. Research has shown that SERVQUAL is a suitable instrument for measuring differences in customer's expectations and perceptions of the pharmacy service quality.

Keywords: pharmacy service quality, customer satisfaction, SERVQUAL, statistical analysis, fear of the COVID-19 virus 